\title{
Flowable Composite
}

National Cancer Institute

\section{Source}

National Cancer Institute. Flowable Composite. NCI Thesaurus. Code C62297.

A tooth restorative material that is formulated to create a loose, free-flowing mix. 